Ann. Biol. anim. Bioch. Biophys., 1979, 19 (4 B), 1387-1390.

\title{
FSH response in prepubertal male and female rats to inhibin-like activity as present in follicular fluid.
}

\author{
par Helma HERMANS, F. H. DE JONG *, R. WELSCHEN \\ Departments of Anatomy and * Biochemistry (Division of Chemical Endocrinology), \\ Medical Faculty, Erasmus University, Rotterdam, The Netherlands.
}

Inhibin-like activity has been shown to be present in a variety of male gonadal fluids (review : Setchell, Davies and Main, 1977). It can be concluded from recent data that charcoal treated bovine and porcine follicular fluid (FF) contains a protein (inhibin) which selectively suppresses levels of radioimmunoassayable follicle stimulating hormone (FSH) when injected into adult male (de Jong and Sharpe, 1976) or female (Welschen et al., 1977 ; Marder, Channing and Schwartz, 1977) rats. Experiments in adult female rats show that relatively large doses of exogenous inhibin did not suppress FSH levels for periods longer than $24 \mathrm{hrs}$. This suggested that inhibin exerts only short term effects on FSH (de Jong et al., 1978). A similar conclusion was reached by Nandini, Lipner and Moudgal (1976) who injected immature male rats with inhibin of testicular origin.

The aim of the present study was to investigate whether FF can exert an inhibinlike feedback action on peripheral FSH concentrations in prepubertal male and female rats and, if so, whether age or sex can influence this suppression.

General procedure : Rats of a Wistar substrain (R-Amsterdam) were used. All operations, injections (i. p.) and blood collections were performed under light ether anaesthesia. At least 6 rats per group were used. Blood was taken $8 \mathrm{hrs}$ after operation or injection by puncture of the ophthalmic venous plexus. Serum was stored at $-20^{\circ} \mathrm{C}$ until essayed for FSH and LH by radioimmunoassay. Bovine plasma (BP) was used as control fluid. Bovine follicular fluid (BFF) was obtained by aspiration of follicles with a diameter of $5-20 \mathrm{~mm}$. Steroid concentrations in BFF and BP were greatly reduced by charcoal treatment as described earlier (Welschen ef al., 1977).

The following experiments were performed:

A. Effect of inhibin-like activity as present in BFF on FSH levels in prepubertal male and female rats.

Male rats of 15, 35, 55 and 75 days of age and female rats of $15,25,35$ and about 75 days of age were used. The latter group was treated at the second day after oestrus, di-oestrus-2. Intact rats or rats bilaterally gonadectomized 2 days earlier were given an injection with $500 \mu \mathrm{l} \mathrm{BP}$ or BFF/100 g. b. w. at $09.00 \mathrm{hrs}$. 
In intact male rats of all ages tested FSH levels were suppressed to 50-70 p. 100 of control values; in intact female rats FSH levels were suppressed to 40 p. 100 of control values at days 15 and 25 , and to 30 p. 100 at days 35 and 75 . Similar results were obtained in rats of the same age groups gonadectomized 2 days earlier.

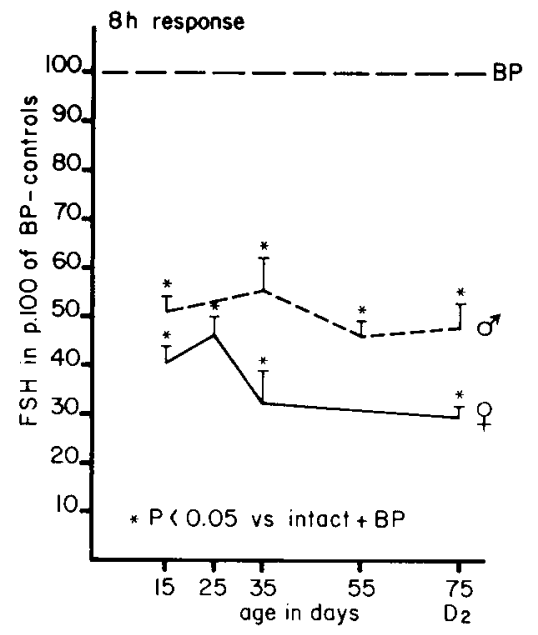

FIG. 1. - FSH (in p. 100 of BP-control values) $8 h$ ofter injection of $500 \mu / \mathrm{BFF} / 100 \mathrm{~g} \mathrm{~b}$. $w$. in intact male and female rats of vorious ages $(n=6)\left(D_{2}=\right.$ di-œstrus-2).

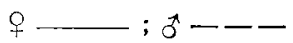

Thus it appears that at all ages tested the hypothalamic-hypophysial system is sensitive to inhibin-like activity, whether the gonads are present or not. Furthermore, if inhibin is produced in the intact animal, removal of the gonads should result in a fast rise of FSH levels. This was tested in experiment B.

B. Short term effects of gonadectomy with or without administration of BFF in prepuberfal male and female rats on FSH levels.

Male rats of 15, 35, 55 and 75 days of age and female rats of 15, 25, 35 and about 75 (at di-œstrus-2) days of age were bilaterally gonadectomized. Animals were bled $8 \mathrm{~h}$ later.

\section{TABLE 1}

FSH (in ng/ml NIAMD-rat-RP-1 or in p. 100 of SHAM-values) $8 \mathrm{~h}$ after bilateral ovariectomy or orchidectomy (BLO) and after BLO followed by an injection of $500 \mu / \mathrm{BFF} / 100 \mathrm{~g} \mathrm{~b}$. $w$. $(\mathrm{n}=6)$ (di-2 = di-œstrus-2)

\begin{tabular}{|c|c|c|c|c|}
\hline \multirow{2}{*}{$\begin{array}{c}\text { Age } \\
\text { (in days) }\end{array}$} & \multirow{2}{*}{ Sex } & \multicolumn{3}{|c|}{ Treatment } \\
\hline & & $\begin{array}{r}\text { SHAM } \\
(\mathrm{ng} / \mathrm{ml})\end{array}$ & $\begin{array}{c}\text { BLO } \\
\text { (p. } 100 \text { of SHAM values) }\end{array}$ & $\begin{array}{c}\text { BLO }+ \text { BFF } \\
\text { (p. } 100 \text { of SHAM values) }\end{array}$ \\
\hline $\begin{array}{l}25 \\
35 \\
\text { di-2 } \\
15 \\
35\end{array}$ & $\begin{array}{l}0 \\
+ \\
9 \\
0 \\
+ \\
0 \\
0\end{array}$ & $\begin{array}{l}316 \pm 14 \\
145 \pm 20 \\
111 \pm 20 \\
367 \pm 34 \\
474 \pm 31\end{array}$ & $\begin{array}{l}216 \pm 19 \\
351 \pm 19 \\
440 \pm 71 \\
162 \pm 13 \\
174 \pm 7\end{array}$ & $\begin{array}{c}87 \pm 17 * \\
167 \pm 49 * \\
55 \pm 10^{* *} \\
92 \pm 17 * \\
56 \pm 2 *\end{array}$ \\
\hline
\end{tabular}

\footnotetext{
$* P<0.05$ vs BLO.
} 
In male rats the FSH response to gonadectomy as compared to intact control values $(=100$ p. 100) decreased with age : 162, 174, 113 and 115 p. 100 at days 15, 35, 55 and 75 respectively. The increase in FSH levels was significant at days 15 and 35.

In contrast, in female rats the FSH response increased with age : 94, 216, 351 and 440 p. 100 at days 15, 25, 35 and 75 respectively. FSH increased significantly at days 25, 35 and 75. Animals of the ages that had shown a significant postcastration rise of FSH levels received an injection with $500 \mu \mathrm{l} \mathrm{BFF} / 100 \mathrm{~g}$. b. w. immediately after gonadectomy. In all these groups the postcastration rise of FSH levels was prevented.

If the observed postcastration rise of FSH levels is the result of a decrease of peripheral concentrations of inhibin, it is likely that inhibin is present in female animals from at least day 25 onwards and in male animals until at least day 35.

In combination these data show that an inhibin feedback mechanism can be demonstrated in male and female rats at all ages tested. However, the FSH regulation by endogenous inhibin seems to become more important towards adulthood in female rats and less important in male rats. The implications of these observations will be discussed.

4th Workshop on " Development and maturation of the reproductive organs and functions 》 Luynes, France, octobre 1978.

Résumé. Le liquide folliculaire de la vache (BFF) contient un facteur (« l'inhibine ») qui diminue le taux circulant de FSH sans modifier le taux de LH. Dans le présent travail, nous avons étudié si l'inhibine participe à la régulation du taux circulant de FSH chez des rattes immatures (mâles et femelles) ainsi que l'influence de l'âge et du sexe sur la diminution de FSH par cette inhibine.

Huit heures après injection du liquide folliculaire (sans stéroïdes), les taux circulants de FSH sont diminués : chez les mâles (âgés de 15 à 75 jours) jusqu'à 50-70 p. 100 en comparaison avec les témoins (qui avaient reçu du plasma d'une vache, BP); chez les femelles (âgées de 15 à 75 jours) jusqu'à 30-40 p. 100 en comparaison avec les témoins.

De plus, en l'absence d'ovaires ou de testicules, la rétroaction négative de l'inhibine peut être mise en évidence. Si l'inhibine est produite chez l'animal intact, la castration doif entraîner une élévation rapide du taux circulant de FSH. Huil heures après castration, une élévation de FSH comparée aux témoins intacts $(=100$ p. 100) est observée : chez les mâles $162,174,113$ et 115 p. 100 à l'âge de $15,35,55$ et 75 jours respectivement, indiquant que l'effet de castration diminue quand l'animal vieillit. Au contraire, l'action de l'ovariectomie sur FSH chez les femelles devient plus forte avec l'âge : 94, 216, 351 et 440 p. 100 à l'âge de $15,25,35$ et 75 jours respectivement. Il a toujours été possible de prévenir l'élévation de FSH après castration par une injection de liquide folliculaire administrée immédiatement après castration.

En conclusion, les résultats montrent une rétroaction négative de l'inhibine chez les rattes mâles ef femelles, immatures ou matures. Il apparaît que l'action inhibine devient plus importante dès l'âge de 25 jours chez la femelle tandis que l'action diminue dès l'âge de 35 jours chez le mâle.

\section{References}

DE JONG F. H., SHARPE R. M., 1976. Evidence for inhibin-like activity in bovine follicular fluid. Nafure, 263, 71-72.

DE JONG F. H., WELSCHEN R., HERMANS W. P., SMITH S. D., VAN DER MOLEN H. J., 1978. Effects of testicular and ovarian inhibin-like activity, using in vitro and in vivo systems. Int. J. Andrology, suppl. 2, 125-138. 
MARDER M. L., CHANNING C. P., SCHWARTZ N. B., 1977. Suppression of serum follicle stimulating hormone in intact and acutely ovariectomized rats by porcine follicular fluid. Endocrinology, 101, 1639-1642.

NANDINI S. G. H., LIPNER H., MOUDGAL N. R., 1976. A model system for studying inhibin. Endocrinology, 98, 1460-1465.

SETCHELL B. P., DAVIES R. V. MAIN S. J., 1977. Inhibin. In JOHNSON A. D., GOMES W. R., The testis, vol. 4, 189-238. Acad. Press, New York.

WELSCHEN R., HERMANS W. P., DULLAART J., DE JONG F. H., 1977. Effects of an inhibin-like factor present in bovine and porcine follicular fluid on gonadotrophin levels in ovariectomized rats. J. Repr. Fert., 50, 129-131. 